\title{
VOORHEES HALL: RUTGERS' FIRST MODERN LIBRARY
}

BY FERNANDA PERRONE

Fernanda Perrone is an archivist and head of the Exhibitions Program in Special Collections and University Archives at the Rutgers University Libraries

The year 2003 marked the I00th anniversary of the dedication of Voorhees Hall, Rutgers' first purpose-built library. Originally known as the Ralph Voorhees Library, Voorhees Hall served as the school's main library from 1903 until the Archibald S. Alexander Library opened in I956. Voorhees Hall can be seen as a case study of the "transitional" library of the late nineteenth and early twentieth centuries, a time when architects and librarians began to work together to design library buildings. Libraries built during this period incorporated the functionality of modern academic library buildings with the monumentality and grace of the book halls of the past. In a broader sense, the history of the Ralph Voorhees Library reflects the evolution of Rutgers from college to state university, and indeed of the development of U.S. higher education in general during the first half of the twentieth century-a period when the growth and diversification of knowledge, and increasing participation in higher education, radically changed the nature of colleges and universities.

\section{Early Libraries at Rutgers}

The origins of the Rutgers library are quite sketchy. During the years after the establishment in I766 of what was then Queen's College, books were donated to the fledgling institution or purchased by whatever funds were available. For instance, in I792, the Reverend Peter Leydt left his library to the college. ${ }^{I}$ Books were stored in various rooms of the Queen's Building, which opened in I8II. Between I8I6 and I825, when Queen's College was dormant and the new building was occupied by the New Brunswick Theological Seminary, the General Synod of the Reformed Church voted small appropriations to purchase books and recommended appointing a

Journal of the Rutgers University Libraries, Volume LXI, pp. I-27

Copyright 2005 by the Rutgers University Libraries. All rights reserved. 
librarian. ${ }^{2}$ A definite location for the library, at the west end of the building on the second floor, is first given in I827. At this time, the library was open from 8:30 to 9:00 A.M. on Saturdays for the circulation of books, under the care of a student librarian. ${ }^{3}$ This was the library for Rutgers College when Queen's College was renamed in honor of Colonel Henry Rutgers in I825.

Although such a system seems inconceivable from a modern perspective, it was actually quite typical of American college libraries before I850. Library historian Jerrold Orne writes that "reading the sparse literature of librarianship and academic history of the years up to I876, one reaches the conviction that leaders of academic institutions then perceived the 'library' as a collection of books, not a building or a place." Rutgers and other former colonial colleges had a rigidly prescribed curriculum delivered through lectures and recitations, which required only a minimum number of standard works. Most college libraries were infrequently used and of little importance. ${ }^{5}$ Many of the books in the Rutgers College library were of a theological nature, reflecting the preponderance of young men preparing for the ministry. More significant were the libraries of the Philoclean and Peithessophian student societies, which developed collections of literary and historical works that students used for the preparation of society papers and debates. ${ }^{6}$ The presence of flourishing student society libraries was quite common at mid-nineteenth-century American colleges. According to a U.S. Bureau of Education survey in I876, Rutgers had 6,8I4 volumes in its college library and 3,800 in society libraries; in fact, the University of North Carolina had 8,394 books in its college library and I3,8I3 in society libraries, while Dickinson College had 7,765 volumes in its library and 19,738 in society libraries. ${ }^{7}$ By the end of the nineteenth century, many college libraries had merged with society libraries, greatly augmenting library collections and contributing to increased hours and greater openness in college libraries. ${ }^{8}$ A similar process happened at Rutgers-but not before the college library was even further diminished by the gradual separation of the college and the New Brunswick Theological Seminary in I856-I864, with the diversion to the seminary of many theological works, which were eventually to be housed in the new Sage Library, built in I875. ${ }^{9}$

Meanwhile, during the first half of the nineteenth century, several professors, including the Reverend Alexander McLelland and P.J.G. Hodenpyl, had taken a special interest in the library. In I863, the Reverend De Witt T. Riley was the first to be listed as "Librarian" in the Rutgers 
catalog, followed by Professor G.W. Atherton from I87I to I880. Professor Isaac E. Hasbrouck appears as "Assistant Librarian" in I868, and he served as librarian from I880 to $1884 .^{10}$ The opening of Kirkpatrick Chapel in 1874, with a library room on the second floor, marked a new era in the history of the Rutgers library. Indeed, the last quarter of the nineteenth century saw dramatic changes in American higher education, with the introduction of new subjects and an elective system, the growing importance of research and graduate study, the appearance of professional schools, and the development of a problem-solving approach in teaching that required the use of many reference sources, as opposed to the earlier lecture-andrecitation method. Academic libraries responded by expanding their collections and hours.

Concurrently, the establishment of librarianship as a profession, with the founding of the American Library Association in 1876, led to the development of professional standards for librarians. ${ }^{11}$ At Rutgers, Merrill Gates, the first professional educator to serve as president, appointed Irving S. Upson in 1884 as the first nonprofessorial librarian, although he also held the posts of registrar, treasurer, and secretary to the faculty. Upson agreed to devote at least one hour a day to library work, for which he received a stipend of \$I5 a month, out of which he paid an assistant $\$ 2.50$ per week. At this time, the library was open daily from 8:00 to 8:40 A.M., noon to I2:30 P.M., and 2:00 to 4:30 P.M. ${ }^{\mathrm{I2}}$ During his two decades as librarian, Upson acquired new collections, increased hours, and served as an advocate for the library, calling for more complete cataloging and better accommodations. ${ }^{13}$ In I894, Upson announced that the library had outgrown its quarters in Kirkpatrick Chapel. At this time, the library held almost 30,000 volumes, an increase of more than 2I,000 since Upson had taken office. Upson reported that in addition to overcrowding, the lighting was poor and insufficient, students were calling for the library to be open all day, and a full-time librarian was needed. ${ }^{\mathrm{I}}$

\section{A New Library for a New Century}

The library gained a strong supporter in Rutgers President Austin Scott (I848-I922), who took office in I890. Scott had received a bachelor's degree from Yale and a Ph.D. from the University of Leipzig. While a

student at Leipzig, Scott assisted historian George Bancroft, then U.S. minister 
to Germany, with the research for Bancroft's multivolume History of the United States. Upon completion of his doctoral degree, Scott took a position at Johns Hopkins University, where he taught a history seminar based on German university techniques. He required students to prepare papers based on original research in primary sources at the Library of the Maryland Historical Society, where the seminar was held. Scott introduced a similar seminar at Rutgers, where he was appointed professor of history, political economy, and public law in I883. The seminar was held in the college library, and Scott constantly directed the attention of students to the primary sources spread out on tables. ${ }^{15}$

In his first President's Statement, Scott wrote that if the library continued its rapid growth, "a separate building for its use will be one of the needs of the not distant future." 16 Scott continued to reiterate this theme through the next decade, stating unequivocally in I894, "We need a good, though not large but substantial fire-proof building for our Library, we need a fund to endow that Library." ${ }^{17}$ The Rutgers Board of Trustees Standing Committee on the Library also expressed concern that books were being stored at diverse locations (including the former library room at Old Queen's), making retrieval difficult. More urgently, the trustees feared fire or a floor collapse. ${ }^{18}$ By I90I, Scott declared that the situation was of crisis proportions, noting that the library's shelves were filled with more than 30,000 books, while over II,000 were piled on the floor. ${ }^{19}$ Moreover, the trustees' committee recognized that the changing use of the library necessitated a different approach to library planning.

In this connection the committee would remind the Board of the great and increasing use made of libraries in all colleges as a practical part of the students life-not as in the time when most of us were in college, where the Library was consulted by students at will \& by many not at all-Today, independent investigation upon the part of each student is encouragedand he is required to refer constantly to the various books of the Library. ${ }^{20}$

The committee went on to recommend finding an alumnus or donor to fund a new library, to which the board agreed. Possibly because of the influence of Scott and his seminar, the Rutgers trustees acknowledged, albeit rather late in the game, the impact of changes in higher education on libraries.

The trustees' decision to seek private funding was not unusual. In the late nineteenth century, as today, college presidents and boards spent a great deal of time soliciting funds from private donors. They distributed 
promotional literature and approached wealthy individuals through letters and personal visits. Prospective donors were promised naming opportunities or the award of honorary degrees. In return, donors sometimes required institutions to provide matching funds, or expected to be closely involved in the execution of their particular project. This was the age of large-scale philanthropy, when figures such as Andrew Carnegie, John D. Rockefeller, Russell Sage, and George Peabody used their fortunes for the support of education and culture. Carnegie, better known for the establishment of public libraries, also donated I08 libraries to American colleges and universities. ${ }^{21}$ In fact, the New Brunswick Free Public Library, funded by Carnegie, was under construction on George Street at the same time as the Ralph Voorhees Library was being built on Hamilton Street. Smaller-scale donations were also common. Apparently, the influence of Carnegie made it fashionable for donors to contribute funds for libraries. Between 1900 and I9I0, 88 percent of academic libraries constructed were funded by private philanthropy, including many libraries at public institutions. ${ }^{22}$

Rutgers was one of those institutions that benefited from this "fashion" in giving. In March 1902, President Scott received a letter from Ralph Voorhees of Clinton, New Jersey, in response to an article in the Christian Intelligencer, the organ of the Reformed Church of America, describing the need for a new library at Rutgers. Voorhees asked for a copy of the preliminary plans that had been prepared and an estimate of the costs. ${ }^{23}$ Who was this mysterious donor? In fact, Ralph Voorhees had long-standing connections to Rutgers College and to the New Brunswick Theological Seminary. Descended from one of New Jersey's oldest Dutch families, he was born in I838 in Mine Brook, near Bedminster, the youngest of eleven children. His father was a prosperous farmer, and young Ralph grew up in rural tranquillity, attending a local school and the Reformed Church at Bedminster. By the age of twenty-two, he had chief responsibility for the 230-acre family farm, which he stayed home to run during the Civil War. During the harvest of I864, he lost the sight in one eye, apparently from a burst blood vessel. Due to atrophy of the optic nerve, he gradually lost the sight in the other eye, becoming completely blind by 1867 . Forced to give up farming, Voorhees remained in the family home, where he was looked after by his sister Ruth. He took an interest in the local library, becoming well versed in history, religion, and social and political life through being read to aloud. 
In 1859, Ralph Voorhees met Elizabeth Nevius Rodman at the Bedminster Reformed Church, where they both sang in the choir. Born in I84I in New York City, Elizabeth was the daughter of John Rodman and his cousin Elizabeth Woodruff Nevius, who died shortly after the couple's daughter was born. Rodman was in the lighterage business, the loading and unloading of ships using barges. Elizabeth was educated at the Moravian Seminary in Bethlehem, Pennsylvania, and, upon graduation, returned to her father's country home in Bedminster. Elizabeth and Ralph became secretly engaged in 1870, but, probably because of Ralph Voorhees' blindness, they did not marry until after her father's death in I887. The couple bought a house in Clinton, where they joined the Presbyterian Church, there being no Reformed Church in the town. They lived in modest comfort until I894, when Elizabeth inherited the estate of her uncle, John Woodruff Rodman. Rodman, who had never married, had entered the importing house of W.W. DeForest in New York at the age of sixteen and had quickly risen to the rank of partner. His estate was valued at $\$ 1,440,000$, mainly in securities, which would appreciate over the years. ${ }^{24}$

Ralph and Elizabeth Voorhees spent the next thirty years donating their fortune to various educational, religious, and cultural institutions, mostly connected with the Reformed or the Presbyterian Church. Although the money technically belonged to Elizabeth Voorhees and she signed the checks, she always made the gifts in her husband's name. Occasionally, the couple gave gifts anonymously, but more often a building, scholarship, or professorship was named in their honor. They frequently made matching gifts and used a variety of investment strategies; for example, Ralph Voorhees made gifts of $\$ 100,000$ in the form of annuities to several institutions. Among the beneficiaries was Presbyterian-affiliated Carroll College in Waukesha, Wisconsin, where Voorhees endowed a Chair of Oratory, Physical Culture, and Composition — with the condition that the president's daughter, May N. Rankin, got the appointment! In fact, the Rankin and Voorhees families were long acquainted through Presbyterian circles in Somerset County. ${ }^{25}$ In I90I, the Voorhees Library at Carroll College was endowed with a gift of $\$ 20,000$. The couple also supported Maryville College in Tennessee, where an Elizabeth Voorhees Chapel and dormitory were established; Lafayette College in Easton, Pennsylvania, only twenty-five miles from their home in Clinton; Coe College in Cedar Rapids, Iowa; and the Reformed Church-affiliated Hope College in Holland, Michigan, which 
had been founded in 1850 to meet the needs of more recent Dutch immigrants. In addition, they supported various religious institutions such as the American Bible Society and the American Tract Society with generous gifts, as well as local churches, libraries, and schools in Bedminster and Clinton. They took a deep interest in the work of the Boards of Domestic and Foreign Missions of the Reformed Church. Probably their most substantial gifts in this area were to what became the Elizabeth R. Voorhees College, a high school for both Hindu and Christian children in Vellore, India. They also supported the School for the Blind at Bombay and various missionaries and schools in China.

Ralph and Elizabeth Voorhees' interest in Rutgers College was a natural outgrowth of their benefactions to the Reformed Church and its institutions. Ralph Voorhees' brother Nathaniel and six of his nephews were graduates of Rutgers College; in fact, Ralph Voorhees visited some of them there in I860 - the only time he actually saw the college (since he was totally blind long before the construction of the library began). Most of the ministers with whom Voorhees and his wife were acquainted were graduates of the New Brunswick Theological Seminary, and, in fact, in 1900, the couple gave $\$ 25,000$ to endow a professorship at the seminary. The recipient, Dr. John H. Gillespie, was the brother-in-law of John G. Fagg, whose work as a missionary of the Reformed Church in Amoy, China, had been supported by the couple since I888.

Voorhees and his wife apparently played little part in the design and building of the Rutgers library. This process was directed by Austin Scott, who involved himself in every detail of the construction, down to the handles on the lavatory doors; a Special Committee of the Board of Trustees, chaired by Scott. Upson, seems to have played a minor role in the process after the initial planning stage, leaving the details of construction to Upson's deputy George A. Osborn, Class of 1897. After serving as a student assistant, Osborn was hired as assistant librarian upon his graduation, and he would virtually be in charge of the library long before Upson's retirement in 1906.

The trustees' committee chose Henry Rutgers Marshall of New York to design the new library. As well as being a descendant of the large Rutgers family of New York and New Jersey, Marshall was an accomplished architect and the author of philosophical and psychological treatises. Born in New York in 1852, he received an A.B. and A.M. from Columbia University. He began to practice as an architect in 1878 and was made a fellow of the 
American Institute of Architects in 1889. He lectured on aesthetics at Columbia, Yale, and Princeton, and he also published Pain, Pleasure, and Aesthetics (I894) and Aesthetic Principles (I895), which was reissued several times. In later years, Marshall served as a member of the Art Commission of the City of New York, and after completing his term as commissioner he was offered the position of secretary, which he held until his death in I927. Under his leadership, the city became a model in planning for municipal art. ${ }^{26}$

By the early I900s, Marshall had designed a number of private homes and public buildings in a variety of architectural styles. His design for the Paul Leicester Ford, Esq., town house on East Seventy-seventh Street in New York, for example, "was a simple brick box that also had bold Italian Renaissance ornament." ${ }^{27}$ Among his other designs were the Bryn Mawr School (I889) on Cathedral Street in Baltimore, the original Brearley School (I890) on Forty-fourth Street in New York, and the Eldridge Gymnasium (I892) in Norfolk, Connecticut. In I892, he was commissioned to design Naulakha in Brattleboro, Vermont, the home that Rudyard Kipling would share for a few years with his American bride, Caroline Balestier. Marshall collaborated with Kipling himself on the design, which was influenced by the English Arts and Crafts movement. Marshall would later design the Frederick A. Brown house, a craftsman-style bungalow in Asheville, North Carolina.

Marshall's design for the Voorhees Library reflected the Neoclassical style, which had grown in popularity since the World's Columbian Exposition of I893 in Chicago. It was also influenced by trends in library construction. While earlier purpose-built libraries had been essentially book halls boasting grand reading rooms with bookshelves forming alcoves, by the early twentieth century, architects were paying some heed to the functionality of the buildings they were designing. Charles C. Soule's "Points of Agreement among Librarians as to Library Architecture," first published in the Library Journal in I89I, had been reissued every year and was widely influential. ${ }^{28}$ Library designers of the period I890-I9I0, which Helen Reynolds has christened the "transitional" stage in library architecture, incorporated some of the monumental features of the earlier book halls, as well as attempting to accommodate the needs of expanding collections and services. ${ }^{29}$ Indeed, Marshall apparently worked with Irving Upson and John Cotton Dana of the Newark Public Library on the initial design of the Voorhees Library. ${ }^{30}$

Marshall designed a symmetrical structure in the shape of a Greek cross, with a central rotunda illuminated by a large skylight, as well as a reading 
room with high windows to admit light. The reading room and rear twostory book stack were supposed to be infinitely extendable. The building also had a minimum number of interior walls, to allow for ultimate flexibility. ${ }^{31}$ The Greek-cross shape was a popular design for academic libraries during the transitional period, because of the potential for extending the "arms" of the cross. In fact, Low Library at Columbia University, built by McKim, Mead, and White in 1897, used this shape on a much grander scale. In his use of a pediment and pilasters on the front facing Old Queen's, Marshall reflected the similar motif of the larger building. The front of the library also had arched entrance doors on each side, reportedly meant to signify "double strength." 32

Marshall wanted the building to be entirely of stone; as he asserted to President Scott, "The Library of a college must always be the center of much of its activity and should be so far as possible of the monumental type." 33 The material he chose was a reddish - brown, rough-cut brownstone. Because of cost, Marshall had to give up his initial idea for a dome over the central rotunda, as well as his plan to make the library completely fireproof. Instead, he used a partly fireproof and partly slow-burning construction, with walls and ceilings either of brick or of plaster on wire laths supported by iron frames. ${ }^{34}$ His use of iron, which had only been adopted for building frames in I884, was one of the ways in which Marshall was able to take advantage of recent advances in building technology and materials. For instance, he had the new library wired for electric light as well as piped for gas. Domes had become popular with architects since the 1895 destruction by fire and subsequent reconstruction of Thomas Jefferson's I826 Rotunda, which at that time contained the library of the University of Virginia. Columbia's Low Library and the Gould Library at New York University's Bronx campus, also built at this time, both had imposing domes. In style, the new Ralph Voorhees Library was chiefly Neoclassical, as shown by its symmetry, simplicity, and restraint, as well as its use of architectural features such as pediments, entablature, and quoins. ${ }^{35}$ The horizontal divisions resembled those seen in neo-Renaissance buildings of the era, such as the Fort Collins, Colorado, Post Office. ${ }^{36}$ In his use of rough-hewn stone, however, Marshall showed the influence of the Romanesque library buildings designed by Henry Hobson Richardson and his contemporaries in the late nineteenth century, such as the Billings Library at the University of Vermont (I886). 


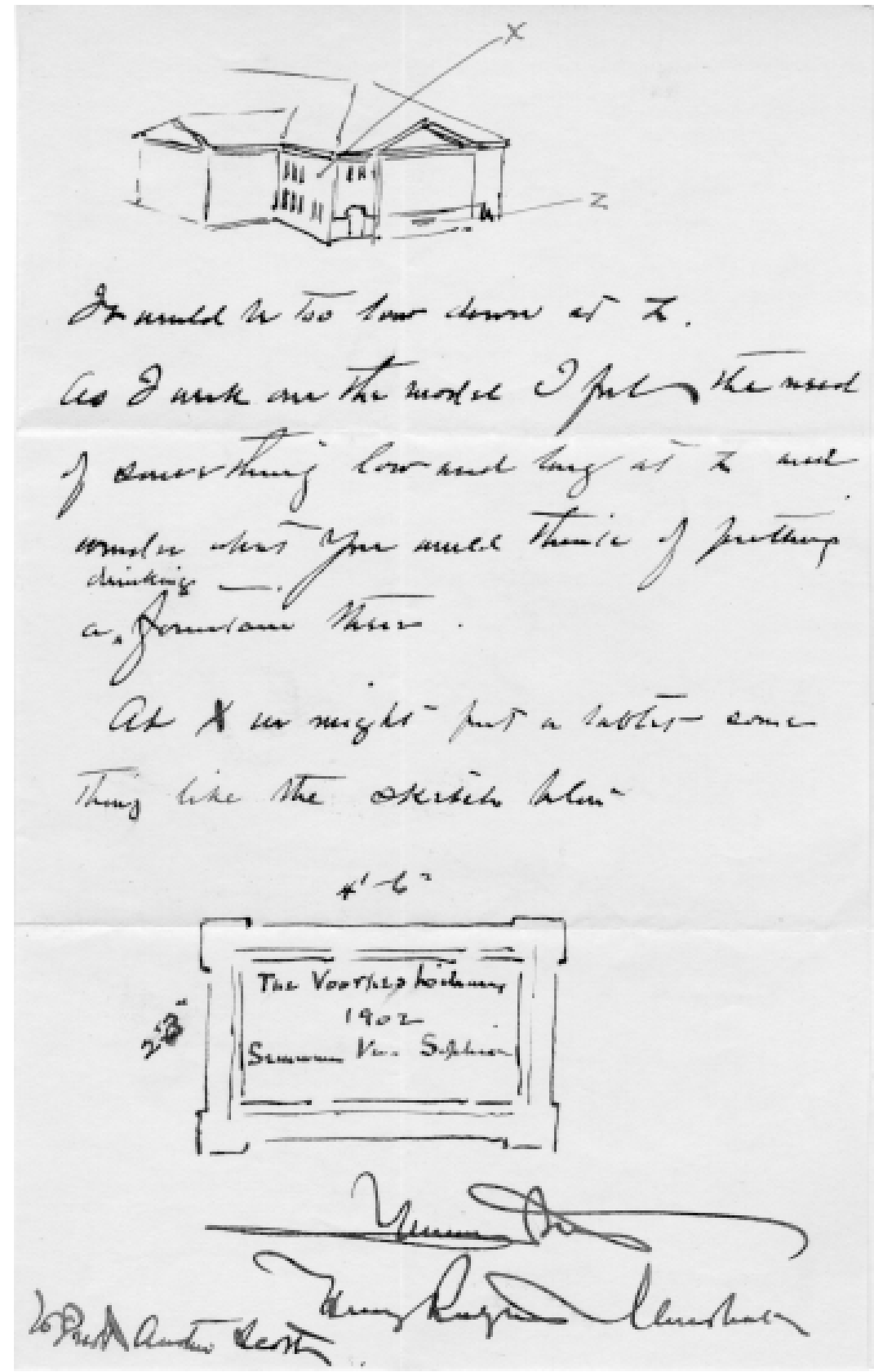

Figure I.I Henry Rutgers Marshall to Rutgers President Austin Scott, letter recommending placement of the inscription on the Ralph Voorhees Library, August 5, 1902. University Librarian's Records, Rutgers University Archives (from Special Collections and University Archives) 


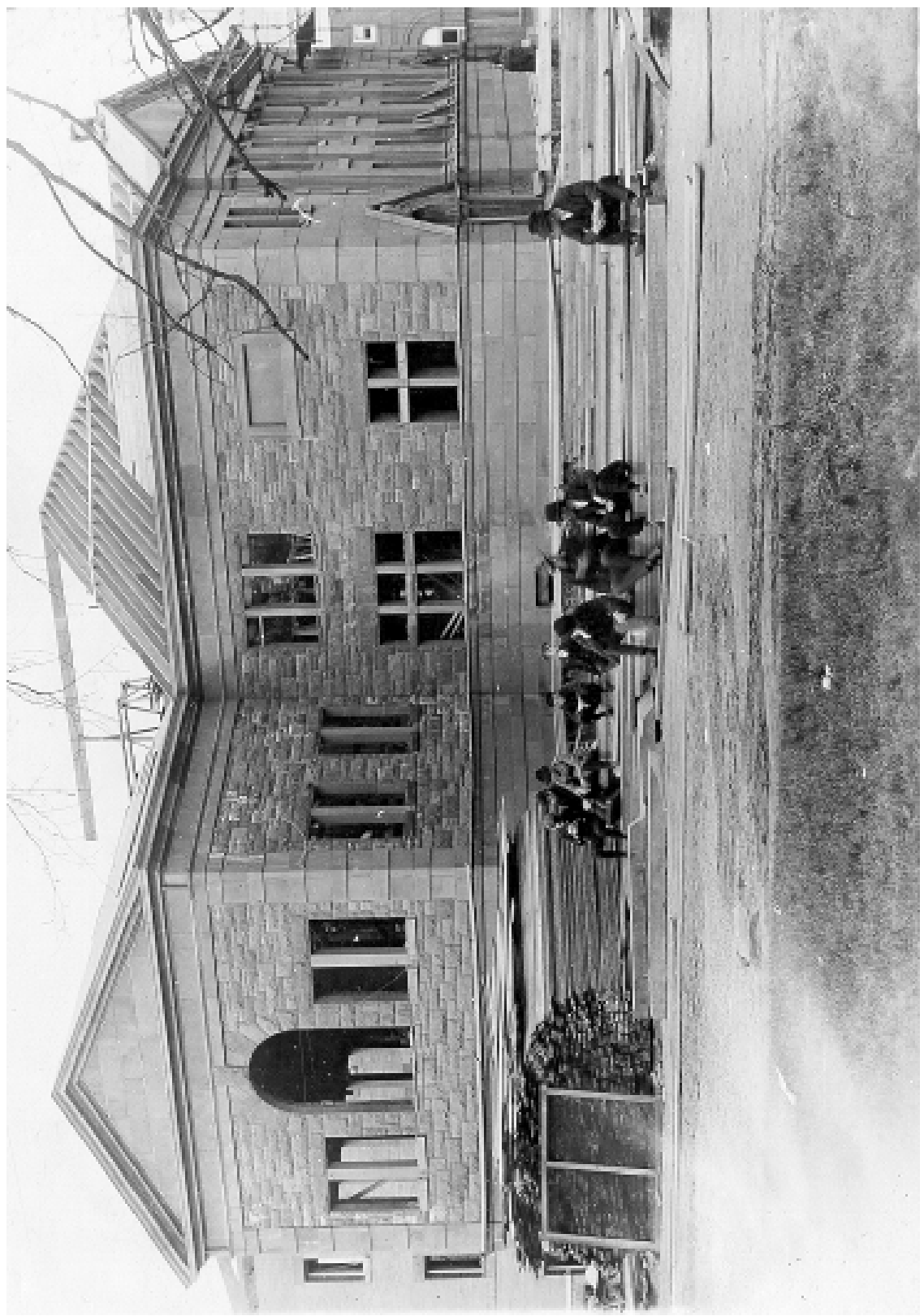

Figure I.2 The Voorhees Library under construction, 1903-I904. Rutgers University Photograph Collection, Rutgers University Archives (from Special Collections and University Archives) 
Apparently, Marshall designed the building without a particular site in mind; several sites on the Old Queen's campus were considered before the trustees settled on part of the land on the opposite side of Hamilton Street that had been donated by James Neilson, between the Ballantine Gymnasium and New Jersey Hall. ${ }^{37}$ Indeed, soon after construction began, Marshall wanted to change the site because of the unevenness of the ground. Reportedly, the shaft of an old copper mine extended below the site, causing the earth to settle. The issue was resolved when the trustees agreed to fund extra work on the foundation; solid ground was struck at fourteen feet. ${ }^{38}$ The trustees chose the construction firm of Merrick of New York, which had recently built the New Brunswick Post Office and was the lowest bidder; this was apparently against the wishes of the architect, who would have preferred a more prestigious firm. Marshall felt that the subcontractors employed by Merrick were not craftsmen of the highest level—noting, after a leak developed in the roof, that the roofer was a Philadelphian! ${ }^{39}$ The construction process was plagued by delays, including an ironworkers' strike that put off the construction of the iron stairways. The building missed its initial completion date of June I5, I903; in fact, in April, to help defray costs, Ralph Voorhees sent $\$ 15,000$ of the $\$ 30,000$ promised on completion of the building.

In the end, the dedication of the building on Charter Day, November I0, I903, took place before it was completely finished. Nevertheless, the event was marked with solemn ceremony and celebration. Ralph Voorhees attended and gave a brief speech, and he and Henry Rutgers Marshall were both awarded honorary degrees. Martin A. Schenck, Class of 1904, spoke on behalf of the students: "Though he enter college with mind as bare as the unfinished walls around us, if he make proper use of this treasure house he will leave with brain as well packed with knowledge as the shelves of this library in a few months will be with books." 40 The following day, Voorhees promised to send an additional $\$ 10,000$ if the university could raise $\$ 4,000$ from other sources in thirty days. ${ }^{4 \mathrm{I}}$ The college was able to meet his challenge through its own funds, donations from individuals, and a subscription among undergraduates, and the completed library opened in January I904. ${ }^{42}$

\section{The Ralph Voorhees Library, 1903-1956}

The new Ralph Voorhees Library would become known as a friendly and welcoming place, largely through the leadership of George A. Osborn, who 
became acting librarian in 1906 and librarian in 1907. Osborn believed in making the library as accessible as possible. Library hours were extended to between 8:00 A.M. and I0:00 P.M. every weekday, and between 8:00 A.M. and 6:00 P.M. on Saturdays. The library's stacks were open for browsing. Even more unusual was Osborn's community borrowing policy, which enabled residents of New Brunswick and the surrounding area to borrow books; furthermore, he imposed no fines for overdue materials. ${ }^{43}$ Osborn was also active in collection development, particularly in the area of New Jerseyana and Americana, and specifically purchasing works on early American economic and social history before these subjects became fashionable.

The first quarter of the twentieth century was a period of rapid growth at Rutgers and, indeed, in higher education in general. A study of a select number of college and university libraries undertaken for the Association of American Universities in 1924 indicated that on average, student enrollment increased 400 percent between 1900 and 1925. Although libraries' collections grew at a similar rate, the authors questioned the ability of librarians to keep up. The study cited the growing body of knowledge, changes in pedagogy, and increased emphasis on graduate study and research as contributing factors. ${ }^{44}$ At Rutgers College, the Ralph Voorhees Library was already almost obsolete by the time it was built. Osborn estimated that when it was completed in 1903, the library had shelving for 30,000 volumes; by I9I0, the library was completely filled and items were placed on the floor. ${ }^{45}$ A floor plan of a proposed enlargement, dated I9I8, can be found in the Rutgers University Archives; however, this plan, which called for four stories of stacks, was never adopted. ${ }^{46}$

Osborn was also concerned about lack of work space, personnel, and funding. In 1923, he noted that he needed money to hire three assistants to carry on a major recataloging of the library; books were being given full Library of Congress call numbers, which were placed on the spine. Osborn observed that "if women are employed it probably will be necessary to pay each trained assistant from \$1500-\$2000." 47 He also commented on the growing cost of books in light of the need to purchase material in new subject areas; the state appropriation for the library could be used only for books in science, economics, and education, reflecting Rutgers' peculiar relationship with the state. ${ }^{48}$ The Rutgers Scientific School, established in I862, had been designated by the state legislature in I864, under the Morrill Act, as the land-grant college for New Jersey, while Rutgers College remained 


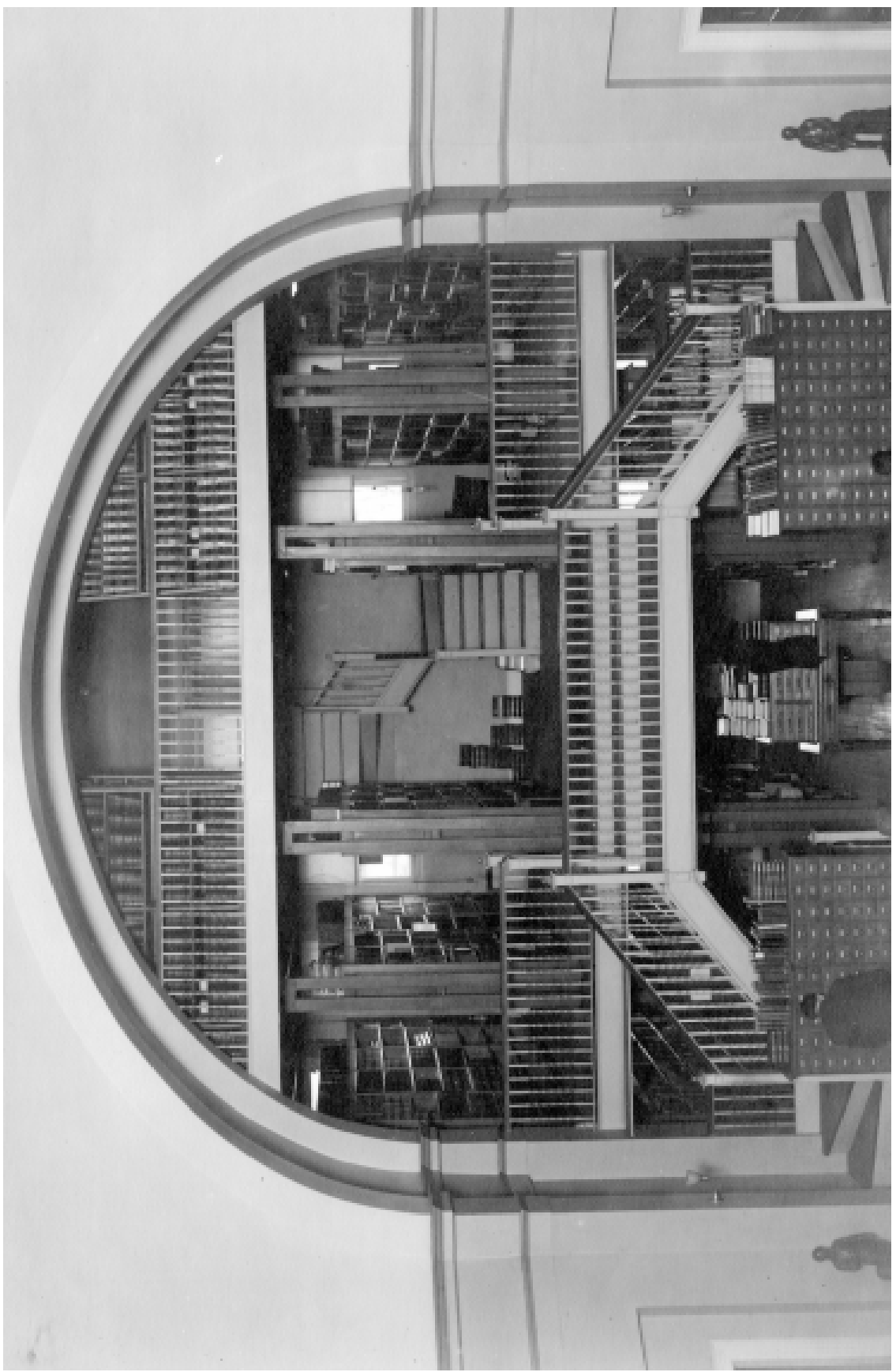

Figure I.3 Original reading room in the Voorhees Library (today part of the Zimmerli Art Museum), ca. 1920. Rutgers University Photograph Collection, Rutgers University Archives (from Special Collections and University Archives) 
a private institution. Thus, the state appropriation could be applied only to areas related to science and agriculture.

An addition to the library, which in fact had been anticipated in the original plan, was clearly needed. After the death of her husband in 1907, Elizabeth Rodman Voorhees had continued his philanthropic pursuits, although perhaps with more of an emphasis on supporting women's education and music; she would ultimately endow the Voorhees Chapel and music program at The New Jersey College for Women (now Douglass College). The college initially approached Elizabeth Voorhees about enlarging the library in 1922; Edward L. Tilton, who had designed the libraries at Swarthmore, Juniata, and Lexington (Kentucky) State Colleges, as well as many public libraries in New Jersey and elsewhere, had already been selected as architect. In 1923, Elizabeth Voorhees gave an anonymous gift of $\$ 150,000$ to fund the library addition —at that time, the second largest gift in the university's history. ${ }^{49}$ Tilton's plan doubled the size of the library by extending the arms of the cross and creating a new entrance between the old and new wings facing Bleecker Place, today the Voorhees Campus_-named not after Ralph and Elizabeth Voorhees, but after statesman Tracy Stebbins Voorhees, who was descended from another branch of the family. The contractors obtained special permission to reopen Longmeadow Quarry, from which the original brownstone had been mined, to extract matching stone. The addition boasted a new reading room that could hold I40 students, with two floors of stacks beneath it, while the old reading room became the Special Collections and exhibition area.

George A. Osborn was intimately involved in the construction of the library addition. He was very concerned that the new structure not repeat the deficiencies of the original design: the low and sloping roof, the small space for shelving as opposed to the ground space occupied by the building, the double entrance and corridors, and the lack of work space, offices, and seminar rooms. ${ }^{50}$ These drawbacks were characteristic of the Greek-crossstyle libraries built at the end of the nineteenth century. More modern libraries were being built to accommodate much larger library collections, while developments in the structure of academic libraries and the profession of librarianship were leading to a growing number of specialized units within the library, which needed to be housed and staffed appropriately. ${ }^{51}$ Osborn reported that Tilton played little role in the construction process, leaving most of it to his assistants. According to Osborn, Tilton's only real 


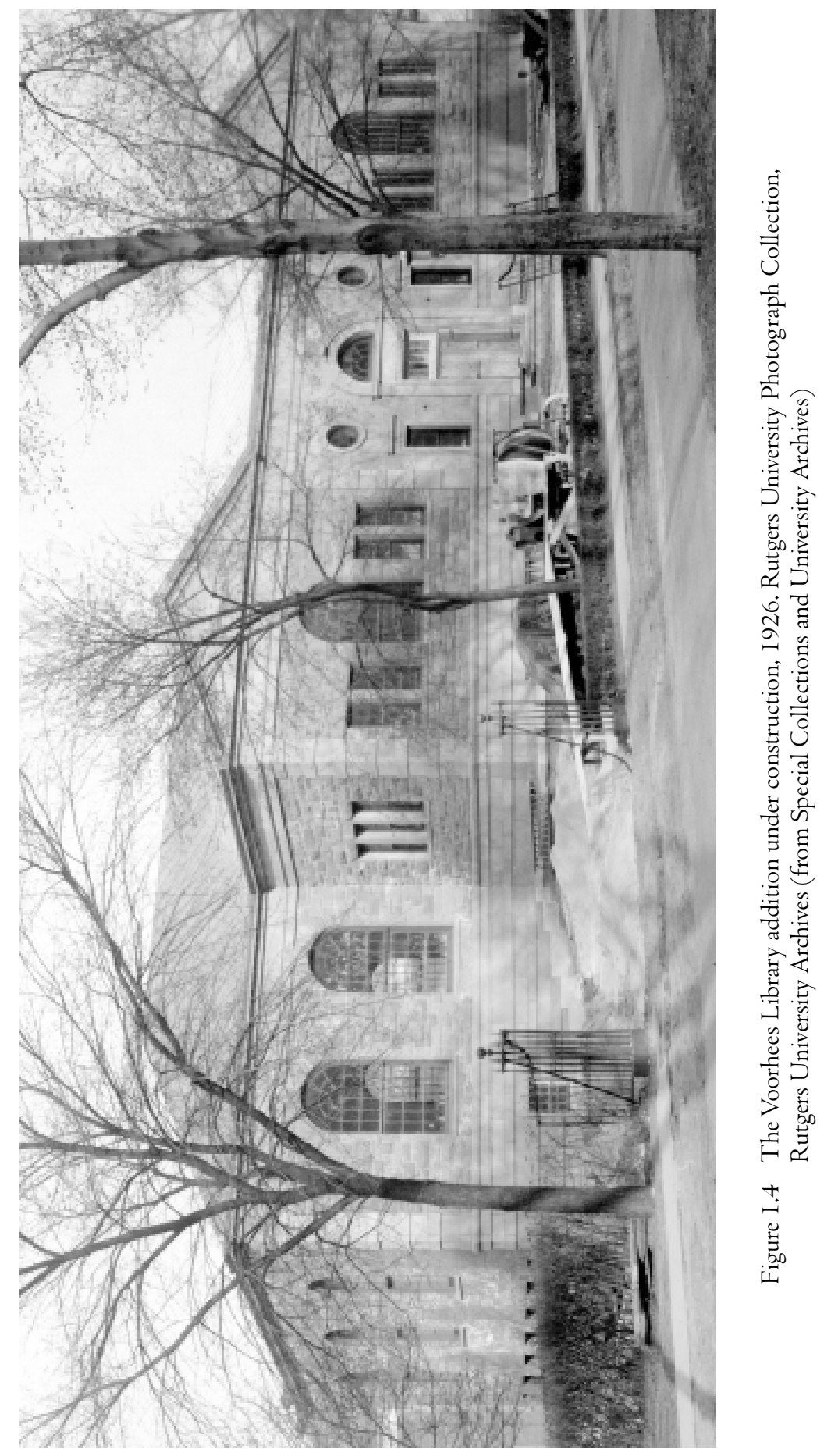




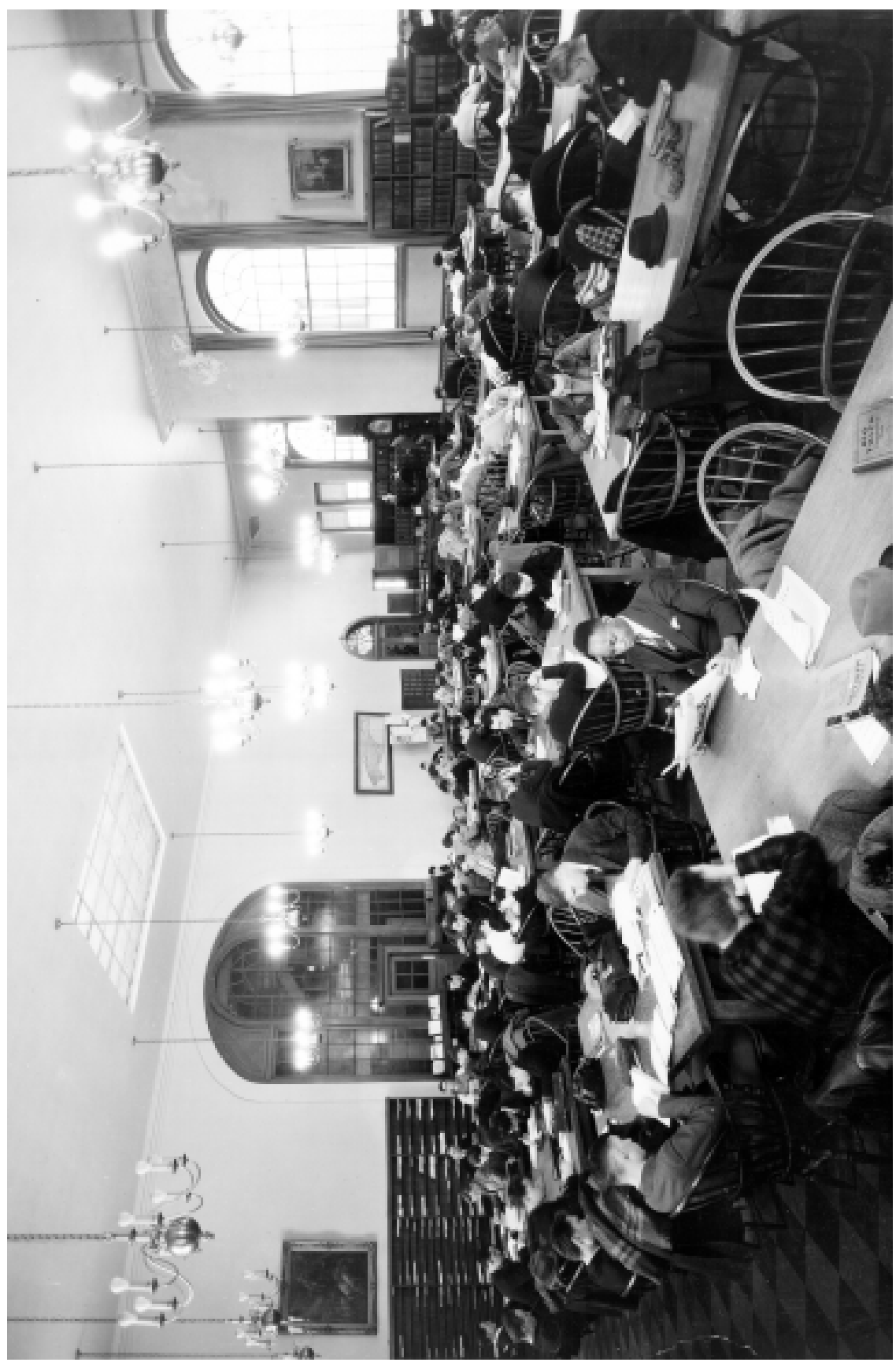

Figure I.5 Students studying in the new reading room, the Voorhees Library, ca. 1934. (C) George H. Pound. Rutgers University Photograph Collection, Rutgers University Archives (from Special Collections and University Archives) 
contribution was the new upper-story reading room; on the other hand, an ambitious plan for a porticoed entrance had to be abandoned because of expense. ${ }^{52}$ In spite of cost overruns, the addition was finished on time, and the library reopened in September 1926.

Not long after the addition was completed, Osborn began a new campaign for increased and better library space, which would continue for the rest of his career. In I93I, he called for plans to be drawn up for a new addition, writing that the growth of the university (Rutgers became a university in 1924), particularly the graduate school, was so great that the library could no longer keep up with the needs of its faculty and students. He noted that in that year the library contained 300,000 items, including books, pamphlets, manuscripts, maps, early newspapers, almanacs, and prints, and had more than I I,000 users a year. ${ }^{53}$ Apparently, the economic depression of the 1930s did little to stem the tide of growth. By 1936, Osborn observed that the Voorhees Library was filled to capacity again, while rooms in the Ballantine building and the basement of Hegeman Hall dormitory were being used for additional storage. ${ }^{54}$ His arguments echoed the earlier concern about overcrowding in the Kirkpatrick Library. Osborn produced statistics showing how poorly the funding and staffing of the Rutgers library compared to its peers: in 1935-1936, the Rutgers library had a staff of 23 and an appropriation of $\$ 23,980$, while the University of Illinois had a staff of 85 and an appropriation of $\$ 115,250$, and the University of Michigan had a staff of 125 and an appropriation of $\$ 125,250$. The Rutgers library still provided full service without a residence requirement; besides Rutgers College students and faculty, its users included students from the New Jersey College for Women, the Agricultural Experiment Station, the Summer Session, public school teachers, state officials, and the personnel of major corporations located in the state. ${ }^{55}$

In 1940, plans were drawn up by University Architect Charles C. Stover, Class of 1913, for a radical expansion of the Voorhees Library. His plan called for quadrupling the building in size, while re-creating Marshall's original symmetrical structure topped with a large flat dome. ${ }^{56}$ Although the library did receive an additional appropriation in I94I, the outbreak of war soon put an end to all construction plans. Osborn retired in 1944, continuing to advocate for an enlarged building and greater funding for library collections and staff. In a poignant reply to an earlier letter congratulating him on his many years of service to the library, Osborn wrote that he felt he had failed in his life's mission: 


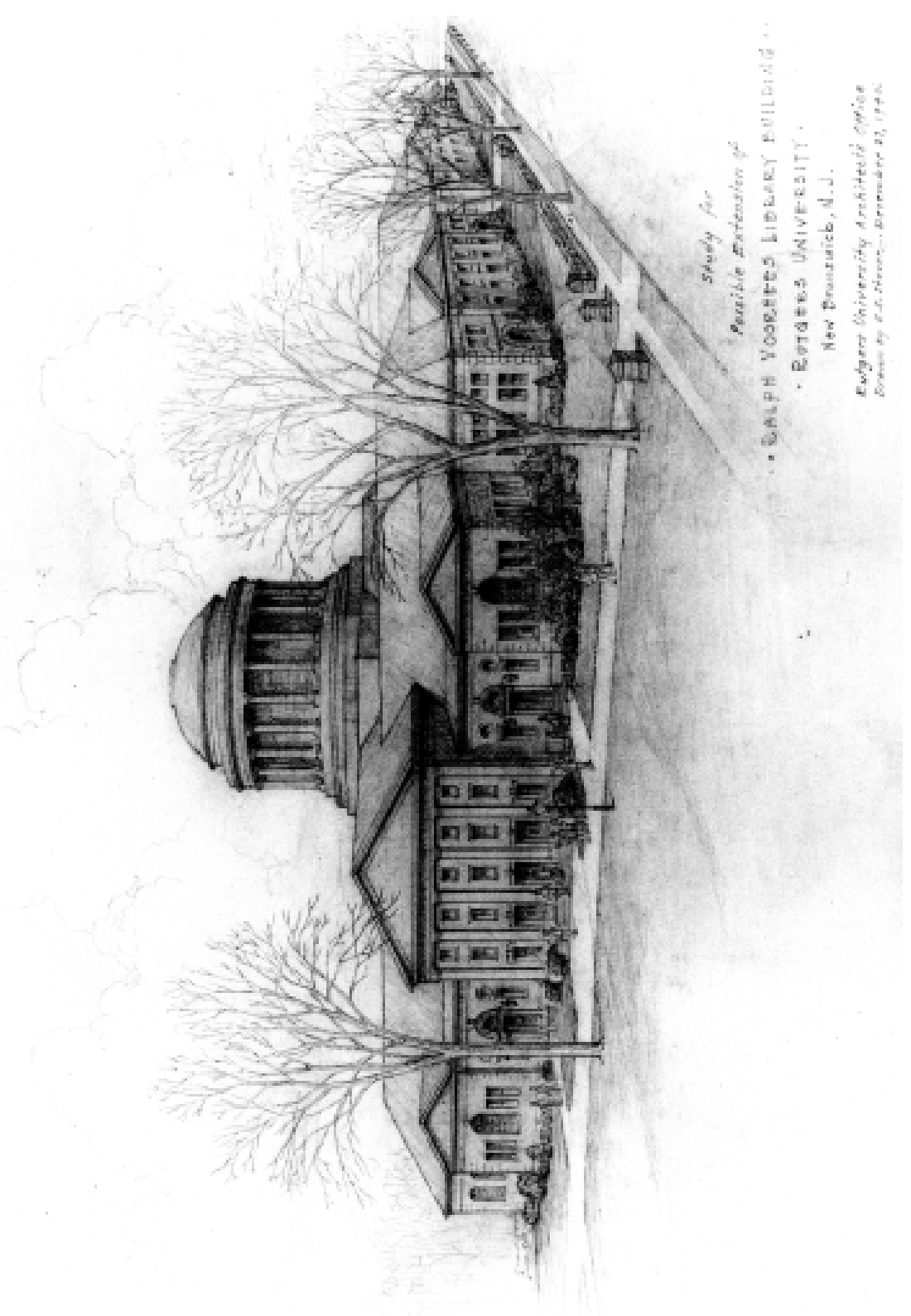

Figure I.6 Study for possible extension of the Ralph Voorhees Library building. C. C. Stover, Rutgers University Architect's Office, 1940. Rutgers University Photograph Collection, Rutgers University Archives (from Special Collections and University Archives) 


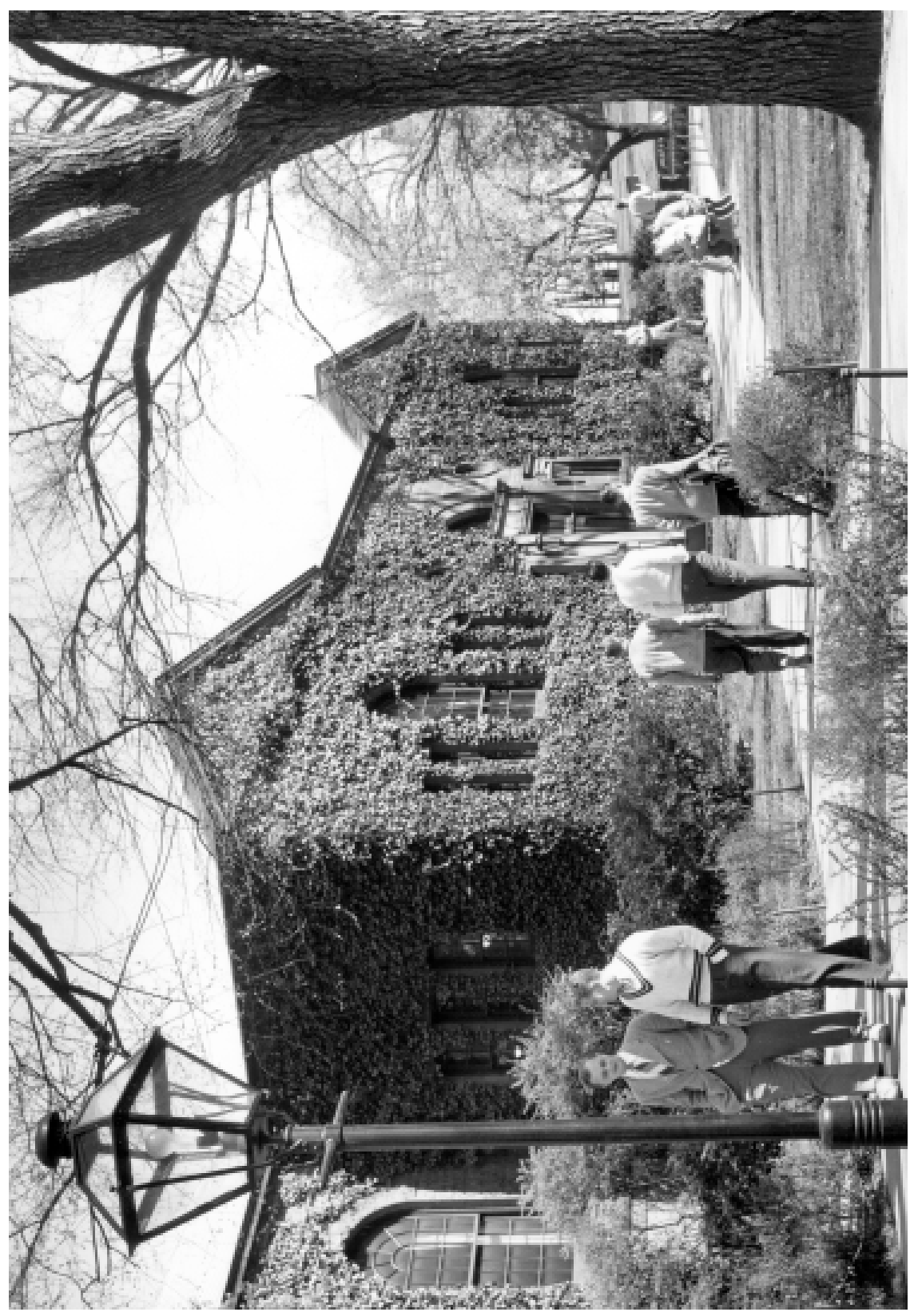

Figure I.7 Students on the mall in front of the Voorhees Library. C F. J. Higgins, I95I. Rutgers University Photograph Collection, Rutgers University Archives (from Special Collections and University Archives) 
This is my $48^{\text {th }}$ year in the Library, and I have had active charge since September 1896. Friends have made kindly remarks about my library work, but they have not mentioned the fact that I have failed in the most important thing of all—that is obtaining sufficient funds to properly provide for the Library needs. I should have done much better in 48 years. ${ }^{57}$

Upon Osborn's retirement, Donald Cameron was appointed as librarian. Born in Scotland, Cameron was a professor of English who was instrumental in the founding of both the Rutgers University Press and the Rutgers Research Council. $^{58}$ Although Cameron accepted that no new library could be built until after World War II was over, he continued Osborn's quest for more space. In 1947-I948, the library opened an annex in New Brunswick and a storage facility on the new University Heights (today Busch) campus. Nevertheless, the lack of space in the Voorhees Library was reaching neardesperate proportions. In I950-I95I, Cameron wrote that with the increasing demands of faculty and graduate students, it was becoming more and more difficult to provide service to the collection, and the shortage of book space was forcing the library to re-evaluate all accessions critically. ${ }^{59}$ meanwhile, however, the war had contributed to far-reaching changes in the relationship of Rutgers University to the State of New Jersey: in 1945, all units of Rutgers were designated as the State University. After the war, the influx of returning veterans swelled the university's enrollment from a prewar high of 7,000 to nearly 16,000 students by $1948 .^{60}$ As a consequence, in I95I-I952, the state legislature voted a $\$ 2$ million appropriation for a new library to serve the entire university. Ground was broken for the new library at the northwest end of College Avenue in September 1953. The Voorhees Library would continue to be used for three more years, until its collections were transferred to the new Archibald S. Alexander Library in the summer of 1956.

\section{Life after the Library}

In 1937, former Rutgers president William H.S. Demarest wrote that "a new library building - allowing surrender of present building to other urgent university needs - is now essential, a building adequate for the present day." ${ }^{61}$ Once a modern university library had been constructed, there seemed to no be thought to retaining the old Voorhees building for any type of library use. After initially housing administrative offices, the building was redesigned 
in 1966 by the firm of McDowell and Goldstein to house the university's first art gallery, as well as the art department and art library. The large front windows were filled in, while three archways containing two doors and a central window beneath signature large white globular lights were added. The interior was remodeled to create a 200-seat lecture hall especially for showing slides. The old rotunda and two wings of the original library housed the new art gallery, which opened in 1967 with an exhibition by American artist William Glackens. ${ }^{62}$

In 1982, Voorhees Hall was again renovated, with the building of a major new addition to the Rutgers Art Gallery, funded by the latest generation of the Voorhees family, Alan and Nathalie Voorhees, as well as by grants and private donations. The new construction quadrupled the size of the exhibition space and added new office and storage areas. The Voorhees Hall gallery itself was renovated and modernized, with the addition of plywood and pasteboard panels for the easier hanging of artwork; it was initially to be used for large temporary exhibitions. ${ }^{63}$ The new structure was renamed the Jane Voorhees Zimmerli Art Museum, in honor of Alan Voorhees' mother, who died in August 1982. The original structure of the Voorhees Library was further hidden with the building of a new art library connected to its north side in I99 I-I992. Moving the art history collections from what had been the lower level of Tilton's stack area into the new building removed the last vestige of the library from Voorhees Hall, but it perhaps fulfilled Marshall's original goal of infinite expandability. Since then, the Zimmerli Museum has continued to expand rapidly, with the addition of a new wing attached to the back of Voorhees Hall in 2000_-meaning that the old structure is now enclosed on three sides by other buildings; indeed, half of Voorhees Hall is actually part of another building, the Zimmerli Museum. Today, Voorhees Hall holds the art history department, classrooms, the Visual Resources Center, and the American wing of the Zimmerli collection.

\section{Conclusion}

The evolution of the Ralph Voorhees Library from small college library to part of a larger conglomerate of buildings mirrors the changing nature of Rutgers over the first half of the twentieth century. During this period, Rutgers developed from a small private college to a large state university. 


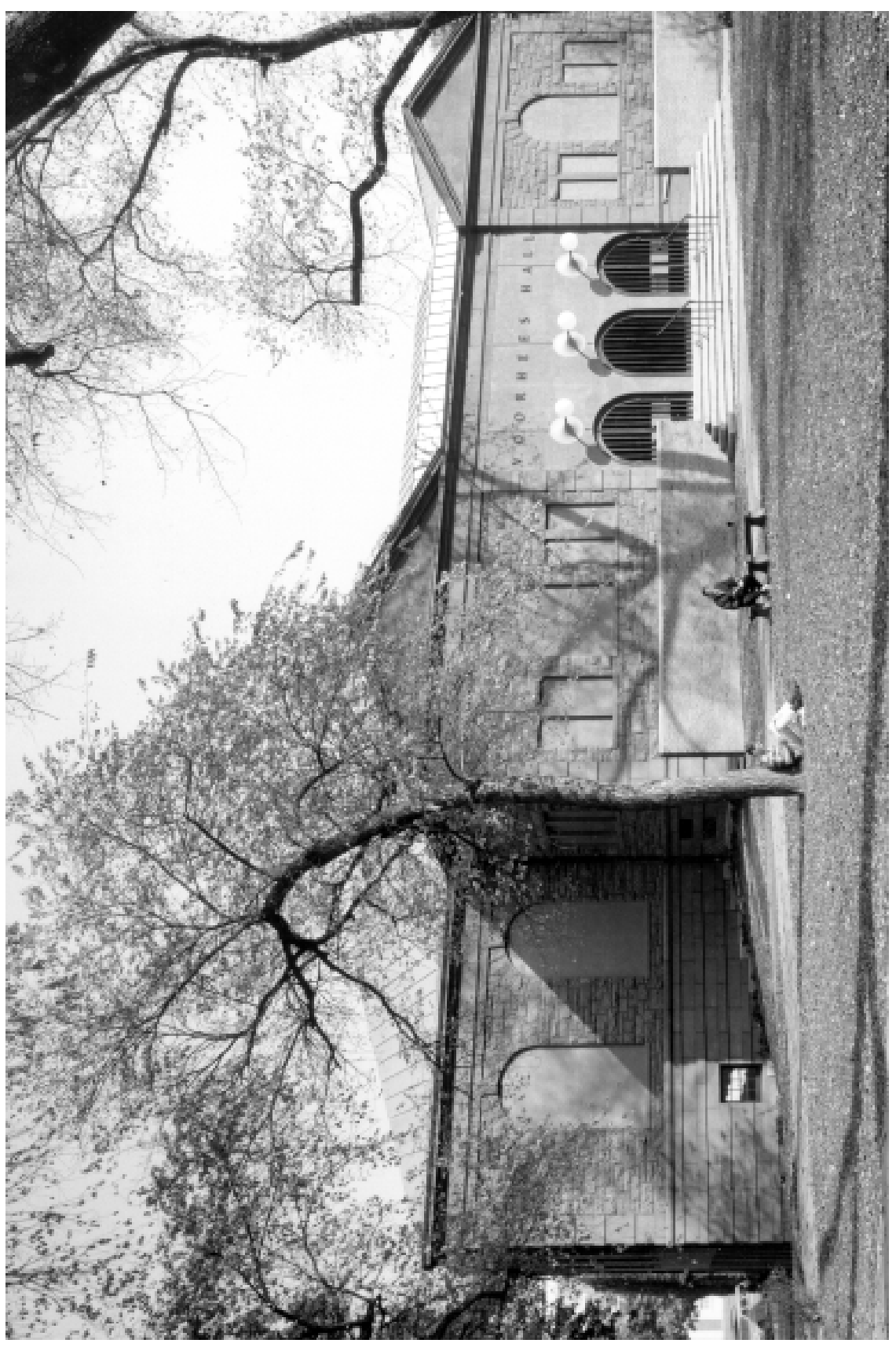

Figure I.8 Exterior of Voorhees Hall after 1966 renovation, showing blocked windows and new doors. (C) Victor's Photography, 1967. Rutgers University Photograph Collection, Rutgers University Archives (from Special Collections and University Archives) 
The growth of Rutgers' faculty and student body, and the expansion of research, graduate study, and professional education, made the small turnof-the-century library increasingly inadequate. Because of lack of funding, however, the Voorhees Library was in use long after many of its contemporaries had been replaced by more modern libraries. In spite of the major expansion of the mid-1920s, the Voorhees Library was far too small for the needs of a modern university. In 1956, there was little interest in preserving the old building, which would be chopped up and used for various university purposes. With the focus on the rapidly changing needs of the library of the present, the charm and tradition of the library of the past were overlooked. Unfortunately, Rutgers University's current system of twenty-six libraries, centers, and reading rooms contains no historic library building. Perhaps an opportunity was lost when the architecturally distinguished and solidly built Ralph Voorhees Library was relinquished.

\section{Notes}

I. W.H. Benedict, "A Skeleton Sketch of Queen's Rutgers Library," ca. 1926. Elizabeth Boyd Collection, Box 2, Rutgers University Archives [hereafter cited as Boyd Collection]. All archival sources are from the Rutgers University Archives.

2. Library Notes, Boyd Collection, Box 2.

3. William H.S. Demarest, "History of the Library," Journal of the Rutgers University Library I, no. I (December I937): 4.

4. Jerrold Orne, "Academic Library Buildings: A Century in Review," in Libraries for Teaching, Libraries for Research: Essays for a Century, ed. Richard D. Johnson (Chicago: American Library Association, I977), I42.

5. David Kaser, The Evolution of the American Library Building (Lanham, MD: Scarecrow Press, 1997), 8-9.

6. Demarest, "History of the Library," 5.

7. Quoted in Edward G. Holley, "Academic Libraries in I876," in Johnson, Libraries for Teaching, 6-7.

8. Ibid., I4.

9. Demarest, "History of the Library," 6.

I0. Benedict, "A Skeleton Sketch," 2-3.

II. Henrik Edelman and G. Marvin Tatum, Jr., "The Development of Collections in American University Libraries," in Johnson, Libraries for Teaching, 34. 
I2. Irving Upson to Merrill Gates, October I, I884(RG 40/AI/02), Rutgers University Office of the University Librarian (George A. Osborn) Records [hereafter cited as Osborn Records], Box 7, Folder I3.

I3. Librarian's Annual Report, October I8, I892, Boyd Collection, Box I.

14. Report to the President of the Board of Trustees and the Committee on the Library, February 26, I894 (RG 03/A0/03), Rutgers University Board of Trustees Records, Minutes \& Enclosures [hereafter cited as Minutes \& Enclosures], Box 9, Folder 4.

I5. L. Ethan Ellis, "Austin Scott and the 'Seminary in History," Journal of the Rutgers University Library I6, no. 2 (June I953): 39-48.

I6. President's Statement, October 27, I89 I, Minutes \& Enclosures, Box 9, Folder I.

17. President's Statement, October 29, I894, Minutes \& Enclosures, Box 9 , Folder 4.

I8. Report of the Committee on the Library of Rutgers College, March 3, I896, Minutes \& Enclosures, Box I0, Folder 6.

19. President's Statement, January I, I90I, Minutes \& Enclosures, Box I I, Folder 2.

20. Report of the Committee on the Library, March I, I90I, Minutes \& Enclosures, Box II, Folder 2.

2I. Donna K. Cohen, "Andrew Carnegie and Academic Library Philanthropy: The Case of Rollins College, Winter Park, Florida." Libraries E Culture 35, no. 3 (Summer 2000): 390-93.

22. Kaser, Evolution, 78-80.

23. Ralph Voorhees to Austin Scott, March 18, 1902, Osborn Records, Box 8, Folder I.

24. See Oscar M. Voorhees, Ralph and Elizabeth Rodman Voorhees: A Tribute (New York: The Tribute Press, 1927).

25. Ibid., I48.

26. Obituary, Henry Rutgers Marshall, American Architect I3I (May 20, 1927): I6, and Henry Rutgers Marshall entry in Dictionary of American Biography, vol. I2 (1933).

27. Robert A.M. Stern, Gregory Gilmartin, and John Montague Massengale, New York 1900: Metropolitan Architecture and Urbanism, 1890 1915 (New York: Rizzoli, I983), 345.

28. Kaser, Evolution, 50. 
29. Helen Margaret Reynolds, "University Library Buildings in the United States," College and Research Libraries I4 (April I953): I52.

30. Rutgers Targum, November 13, 1902.

3I. Henry Rutgers Marshall to Austin Scott, July I6, I902, Osborn Records, Box 8, Folder I, and New Brunswick Home News, September I I, 1902.

32. New Brunswick Sunday Times, October 22, I 922.

33. Henry Rutgers Marshall to Austin Scott, July 16, I902, Osborn Records, Box I, Folder I.

34. Henry Rutgers Marshall to Austin Scott (July I8, 1902), Osborn Records, Box I, Folder I, and New Brunswick Home News, September II, 1902.

35. A pediment is defined as the triangular area over the portico of a building. In Neoclassical architecture, an entablature is any feature similar to the Classical entablature, the superstructure carried by the columns and divided horizontally in three. Quoins are stone or brick corner decorations. Grove Art Online (Oxford University Press, 2004).

36. Colorado Office of Historic Preservation, A Guide to Colorado Architecture, http://www.coloradohistory-oahp.org/guides/architecture/styles/.

37. Lori Starr and Richard Strobel, "Voorhees: The Evolution of a Campus Building," Rutgers Alumni Magazine (September 1976): I4.

38. Special Committee on the Erection of the Ralph Voorhees Library Building, October 18, 1902, Osborn Records, Box 7, Folder I4, and Rutgers Targum, November I4, 1902.

39. Henry Rutgers Marshall to Austin Scott, March I0, I904, Osborn Records, Box 8, Folder I.

40. Address by Martin A. Schenck, November I0, I903, Osborn Records, Box 8, Folder 2.

4I. Ralph Voorhees to Austin Scott, November II, I903, Osborn Records, Box 8, Folder I.

42. President's Statement, January I4, I904, Minutes \& Enclosures, Box I2, Folder 2.

43. New Brunswick Sunday Times, October 22, 1922, and Rutgers Alumni Montbly 26 (June 1947): I6.

44. Stanley McElderry, "Readers and Resources: Public Services in Academic and Research Libraries, I876-1976," in Johnson, Libraries for Teaching, 60. 
45. Statement of the Librarian to the President and to the Members of the Library Committee of the Board of Trustees, March 24, I936, Osborn Records, Box 7, Folder 9.

46. Floor Plan, Proposed Enlargement, Voorhees Library, R-Photo, Buildings and Grounds, Box 16.

47. George Osborn to H.P. Schneeweiss, Treasurer, Trustees Library Committee, March 9, I923, Osborn Records, Box 7, Folder 9.

48. Ibid.

49. Rutgers Alumni Montbly (November I923).

50. Notes on library addition, 1924-1926, Osborn Records, Box 8, Folder 4.

51. Reynolds, "University Library Buildings," I52-56.

52. John Wyckoff Mettler to Edward L. Tilton, March I7, I925, and George Osborn to J.W. Mettler, June I6, I925, Osborn Records, Box 8, Folder 5.

53. Report of the Committee on the Library at Meeting of the Trustees, April 10, 1930, and George Osborn to Frank Bergen, chairman, April 16, I93I, Osborn Records, Box 7, Folder 9.

54. Statistics enclosed with A Statement of the Librarian to the President and to the Members of the Library Committee, March 24, I936, Osborn Records, Box 7, Folder 9.

55. Report of the Committee on the Library, 1926, Osborn Records, Box 7, Folder 9.

56. Starr and Strobel, "Voorhees," I6.

57. George Osborn to Richard Greene [carbon], January I4, I94I, Osborn Records, Box 7, Folder I0.

58. Peter Charanis, "Donald F. Cameron," Journal of the Rutgers University Library 29, no. 2 (June 1966).

59. Annual Report, I950-I95I (RG 40/AI/03), Rutgers University Office of the University Librarian (Donald Cameron) Records, Box I, Folder 6.

60. Richard P. McCormick, Rutgers: A Bicentennial History (New Brunswick: Rutgers University Press, I966), 27I.

6I. Demarest, "History of the Library," 8.

62. David Schreiber, "Campus Art Center," Newark Sunday News, May 2I, 1967.

63. Doris E. Brown, "Rutgers Gallery Assumes New Name, Old Director," New Brunswick Home News, July 25, 1982. 